\title{
Prevalence of excessive screen time and associated factors in a school from a city in the northeast of Brazil
}

\author{
Hector Luiz Rodrigues Munaro', Diego Augusto Santos Silva², Adair Da Silva Lopes ${ }^{2}$
}

DOI: http://dx.doi.org/10.7322/jhgd.122821

\begin{abstract}
:
Introduction: Studies about screen time and its correlates are generally determined by the sum of the duration of several behaviours. Studies that analysed behaviours separately highlighted different correlates.

Objective: Estimate the prevalence of excessive screen time, through watching television and using computers or video games, and its correlates, in students in a city in North-eastern Brazil.

Methods: An investigation in a high school located in the city of Jequie, Bahia state, Brazil, with a sample of 1163 students between 14 and 20 years. The dependent variables were excessive time watching television and using computers or video games, and the independent ones were socio-demographic and lifestyle variables. The magnitude of the association was determined by the Odds Ratio (OR) and by $95 \%$ of confidence intervals $(\mathrm{Cl})$.

Results: The prevalence of excessive time watching television was estimated at $32.8 \%$ (95\% Cl: $29.9 \%-35.5 \%)$ and using computer/videogames was $27.3 \%(95 \% \mathrm{Cl}: 24.5 \%-29.5 \%)$. Those who did not work (OR $=1.940 ; 95 \% \mathrm{Cl}: 1.365-2.758)$; those students whose mothers had less than eight years of schooling (OR $=1.324 ; 95 \% \mathrm{Cl}$ : $1.023-1.714)$; and who did not regularly eat vegetables $(\mathrm{OR}=1.423 ; 95 \% \mathrm{Cl}: 1.082-1.871)$ were more likely to be exposed to excessive television. On the other hand, those who had not reached the minimum consumption of fruits (OR $=0.712 ; 95 \%$ $\mathrm{Cl}: 0.245-0.929)$ showed lower odds. Female students ( $\mathrm{OR}=0.694 ; 95 \% \mathrm{Cl}: 0.528-0.912)$ and students with family income lower than two minimum wages ( $\mathrm{OR}=0.630 ; 95 \% \mathrm{Cl}$ : $0.474-0.838)$ had lower chances of exposure to excessive time using computer/video games, while the insufficiently active (OR $=1,557 ; 95 \% \mathrm{Cl}: 1,076-1,972)$ showed higher chances.
\end{abstract}

Conclusions: About $1 / 3$ of the students spent too much time in front of the television and computer/ video games, with a different correlation relative to each of these behaviours.

Keywords: sedentary, adolescents, risk factors, behaviour.

\section{INTRODUCTION}

Sedentary behaviour is defined as a set of activities with energy expenditure close to rest values, typically held in a sitting position, including activities such as watching television, using a computer, playing video games, talking on the phone, or talking with friends ${ }^{1,2}$. One of the most used criteria to estimate the time sitting watching television and in front of a computer or video game, considers those who spend two or more hours a day in front of such a device to be engaging in sedentary behaviour ${ }^{3}$. In recent years, use of the term "screen time" has emerged as a way to analyse this sedentary behaviour in studies with scholars, being defined as one of the dimensions of sedentary behaviour, held in front of a screen. This includes watching television, using a computer and playing video games (with the exception of interactive games and portable devices), when used in a seated position or lying down ${ }^{2}$.

A study that estimated the prevalence of sedentary behaviour related to the screen time, conducted in 2005/2006, with data from 40 countries of Europe and of the United States, showed that $66 \%$ of male and $68 \%$ of

1 Universidade Estadual do Sudoeste da Bahia. Campus de Jequié. Departamento de Saúde I.

2 Universidade Federal de Santa Catarina, Centro de Desportos. Campus Universitário Trindade, Departamento de Educação Física. Corresponding author: Hector Luiz Rodrigues Munaro - Email: hlrmunaro@uesb.edu.br

Suggested citation: Munaro HLR, Silva DAS, Lopes AS. Prevalence of excessive screen time and associated factors in school of a northeast city. J Hum Growth Dev. 2016; 26(3): 360-367. DOI: http://dx.doi.org/10.7322/jhgd.122821

Manuscript submitted: 22 May 2016, accepted for publication 16 Jun 2016. 
female teenagers spent two or more hours a day watching television, where the maximum recommended time is less than two hours ${ }^{2,4}$.

The National Survey of Scholar Health (PeNSE) ${ }^{5}$, held in 2012 in Brazil, with data from 26 capitals and the Federal District, estimated the prevalence of excessive time in front of the television to be $78.6 \%$ for schoolchildren of around 15 years old. This behaviour, combined with other factors, can be harmful to the health of those still in adolescence, resulting in increased levels of body fat, decreased efficiency of the musculoskeletal system and problems with social relations ${ }^{6}$. In addition, the sedentary lifestyle increases the risk of acquiring some morbidities, such as diabetes, obesity and hypertension, during later adult life ${ }^{7,8}$.

Despite some disagreements, studies have pointed to some correlated related to screen time. A systematic review, conducted to estimate the prevalence of risk behaviour among schoolchildren, found that, in most studies, sedentary behaviour (screen time) was linked to female students under 15 years with low monthly household income and parents with a low educational level ${ }^{8}$. However, another review showed that sedentary behaviour was more common for males, particularly those that are overweight or obese and those with parents with a low educational level ${ }^{9}$. The conflicting results of studies, in relation to the prevalence and related estimates, suggest a variation in the use of the measure (total or separate time, week or weekend), the age groups and the designs of the studies (longitudinal or transverse) $)^{10-12}$.

In general, studies have investigated screen time and its related correlates by adding the screen time or total time (time watching television and computer/video games $)^{13,14}$. Despite being scarce, studies that investigated screen time correlated separately demonstrated that, on the same sample, such factors can be different ${ }^{15,16}$. However, these studies were performed in middle income countries and in major centres, thus, justifying the need for studies in other circumstances.

In light of the divergence related to the different types of sedentary behaviours based on screen time and the predominance of searches in major urban centres of developed regions, this study aimed to estimate the prevalence of excessive screen time ( $\geq 2$ hours/day), either watching television or using computer/video games, and to verify the possible associations to socio-demographic factors and lifestyle in a school in a city in the Northeast of Brazil.

\section{METHODS}

This is a school-based and analytical study, which is an integrative part of a project monitoring health risk behaviours in schools in the city of Jequié, Bahia, Brazil. The city of Jequié is located in the Northeast region, about $370 \mathrm{~km}$ from Salvador, with a population of around 151,895 inhabitants and a Human Development Index (HDI) score of 0.694 . The economy of the municipality is based on the retail trade ${ }^{17}$ and it is considered a regional pole of education (Core Regional Education), responsible for the management of all State schools in 16 municipalities and districts of the Territory of Identity of the Middle River.

\section{Population and sample}

The population of this study comprised 3,040 students of 98 school groups of all 12 State urban public schools in the municipality, duly enrolled in high school, in morning and afternoon sessions in 2015. The sample was selected randomly and proportionate by conglomerates in two phases ${ }^{18}$.

The parameter for determining the sample was the estimated prevalence of the phenomenon that, due to the large number of variables to be studied, was $50 \%$. The confidence interval was $95 \%$ and adopted maximum error of three percentage points. However, as the sample was by conglomerates, for the purpose of design, this value multiplied by 1.5 and later added $15 \%$ for cases of loss or refusals. So, the minimum sample was 1,388 . The selection for conglomerates was held in two stages. In the first, the sample unit were schools, having selected those from the urban area that offered high school in the morning and afternoon sessions $(n=12)$, on the condition that there was no refusal on the part of managers. Rural schools $(n=3)$ and annexes of urban schools were not part of the sample, due to classes being offered in night sessions, and nor was the military police School, whose teaching model differs from other schools.

In the second stage, the sampling units were the classes, selected in a manner proportional to the number of grades, with around 30 students per class. These were selected by lot, with 48 classes in order to achieve the necessary size of the sample.

There was a refusal for participation from $135 \mathrm{stu}-$ dents. In addition, 83 minors, did not participate because they did not deliver the terms on the day of collection, and seven did not respond to questions concerning the dependent variables, resulting in a sample loss of $6.5 \%$ $(\mathrm{n}=90)$.

\section{Data collection procedure}

Data collection took place in July and August 2015. We used a valid and previously tested instrument ${ }^{19}$ with good repeatability indices, using the Kappa coefficient $(\mathrm{k}=0.485$ to $\mathrm{k}=1)$ and the correlation of Spearman (rho $=0.483$ to rho $=0.960)$, which was applied in the classroom by previously trained interviewers, with average time of 28 minutes. The questionnaire was self-administered and contained information divided into six blocks. Variables

In this study, the dependent variables (screen time of television and computer/video games) were author-referred by scholars on two issues: the first about television: "how many hours a day do you watch television?"19, and the second: "how many hours a day do you use your computer and/or play video games?"19. The responses were categorised as either " $<2$ hours/day" or " $\geq 2$ hours/day".

The independent variables were gender; age, being categorised into " $\leq 14$ years", "15 to 16 years", "17 to 18 years" and "> 19 years"; employment status (employed and unemployed); marital status (single and married/oth- 
er); school grade (1st, 2nd and 3rd grade); mother's education ( $<8$ years of study and $\geq 8$ years of study); and monthly family income $(<2$ minimum wages and $\geq 2$ minimum wages). During the data collection period, the minimum wage was R\$788.00 (\$225.00).

Independent variables related to lifestyle were the consumption of fruits and vegetables, using the consumption of a daily portion as a criterion, categorised as inappropriate consumption " $<5$ days/week" and appropriate consumption "> 5 days/week"; and consumption of alcohol and smoking, using as a criterion the consumption regardless of the number of doses or cigarettes, categorised as either "Yes" or "No". The level of physical activity was investigated by means of a question on the frequency of exercise: "During a normal week (typical), how many days do you practice moderate to vigorous physical activities (physical activity in leisure, at work and in commuting)?"'19; and another question about the length: "During a normal week (typical), how long do you practice moderate to vigorous physical activities (physical activity in leisure, at work and in commuting)? ${ }^{19}$ ". Those who had not accumulated the minimum recommended exercise of 60 minutes per day at least five days a week were considered insufficiently active ${ }^{20}$.

\section{Statistical analysis}

We used the descriptive statistics (relative and absolute frequency) and, for inferences, the Chi-square test and logistic regression. The magnitude of the effects on the outcomes was measured by the Odds Ratio (OR) and their confidence intervals (CI) of $95 \%$, according to the theoretical assumptions found in literature ${ }^{21}$. The independent variables were analysed individually, and those that presented a value of $<$ p 0.20 in analysis of univariate approach were included in the final model. Attached to the outcome we considered those variables with value of $<$ $0.05 \mathrm{p}$. The statistical package SPSS for Windows version $15{ }^{\circledR}$ was used and adopted for data analysis and interpretation of $95 \%$. Since the study was about a sample by conglomerates, the effect of design was corrected using the command ".csplan" for complex samples ${ }^{22}$.

\section{Ethical issues}

The protocols were approved by the Committee of ethics in research with Human Beings at the Universidade Estadual do Sudoeste da Bahia, with the number $83,957 / 14$. Participants were provided with the terms of consent and Assent (under 18 years) and signed for the authorisation of data collection. In the case of minors, their parents or guardians signed the terms for them.

\section{RESULTS}

In this study, the sample was composed of 1,163 scholars, with the larger proportion being women (57.9\%; $n=678)$. The descriptive characteristics of the sample are presented in Table 1. The estimated prevalence of excessive screen time watching television ( $\geq 2$ hours/day during the week) was $32.8 \%$ (95\%CI: $29.9 \%-35.5 \%)$ and computer/video game was $27.3 \%$ (95\%CI: $24.5 \%-29.5 \%)$. (Table 1).
Table 1: Descriptive characteristics of the sample. Jequié, Bahia, Brazil, 2015

\begin{tabular}{|c|c|c|c|}
\hline Variables & $\%$ & $\mathrm{n}$ & $\mathrm{Cl}(95 \%)$ \\
\hline \multicolumn{4}{|c|}{ Dependents } \\
\hline \multicolumn{4}{|c|}{ Screen time television } \\
\hline$\geq 2$ hours/day & 32,8 & 381 & $30,2-35,6$ \\
\hline$<2$ hours/day & 67,2 & 782 & $64,6-70,0$ \\
\hline \multicolumn{4}{|c|}{ Screen time Computer/Videogame } \\
\hline$\geq 2$ hours/day & 27,3 & 317 & $24,6-29,8$ \\
\hline$<2$ hours/day & 72,7 & 846 & $70,2-75,4$ \\
\hline \multicolumn{4}{|c|}{ Socio demographical } \\
\hline Female & 57,9 & 678 & $55,3-60,8$ \\
\hline Male & 42,1 & 492 & $39,2-44,7$ \\
\hline \multicolumn{4}{|l|}{ Age (years) } \\
\hline$<14$ & 3,4 & 40 & $2,5-4,5$ \\
\hline $15-16$ & 48,6 & 569 & $45,7-51,5$ \\
\hline $17-18$ & 40,7 & 476 & $37,9-43,4$ \\
\hline$>19$ & 7,3 & 85 & $5,9-8,8$ \\
\hline \multicolumn{4}{|l|}{ School grade } \\
\hline $1^{0}$ & 41,7 & 488 & $38,9-44,5$ \\
\hline $2^{\circ}$ & 30,9 & 362 & $28,2-33,5$ \\
\hline $3^{0}$ & 27,4 & 320 & $24,8-28,9$ \\
\hline \multicolumn{4}{|l|}{ Marital Status } \\
\hline Single & 88,5 & 1035 & $86,5-90,3$ \\
\hline Married (a) & 11,5 & 135 & $9,7-13,5$ \\
\hline \multicolumn{4}{|l|}{ Occupation } \\
\hline Does not work & 81,4 & 952 & $79,2-83,5$ \\
\hline Works & 18,6 & 218 & $16,5-20,8$ \\
\hline \multicolumn{4}{|c|}{ Mother schoolarity (years of study) } \\
\hline$<8$ years & 38,0 & 445 & $35,2-40,8$ \\
\hline$\geq 8$ years & 62,0 & 725 & $59,2-64,8$ \\
\hline \multicolumn{4}{|c|}{ Monthly Family Income (minimum) } \\
\hline$<02$ salaries & 71,3 & 834 & $68,7-73,8$ \\
\hline$\geq 02$ salaries & 28,7 & 336 & $26,2-31,3$ \\
\hline \multicolumn{4}{|l|}{ Lifestyle } \\
\hline \multicolumn{4}{|l|}{ Fruit consumption } \\
\hline Inadequate & 54,8 & 634 & $52,0-57,8$ \\
\hline Adequate & 45,2 & 522 & $42,2-48,0$ \\
\hline \multicolumn{4}{|c|}{ Vegetables consumption } \\
\hline Inadequate & 60,8 & 693 & $57,9-63,9$ \\
\hline Adequate & 39,2 & 446 & $32,1-46,1$ \\
\hline \multicolumn{4}{|c|}{ Alcohol consumption } \\
\hline Yes & 23,8 & 277 & $21,5-26,1$ \\
\hline No & 76,2 & 887 & $73,9-78,5$ \\
\hline \multicolumn{4}{|c|}{ Tabaco consumption } \\
\hline Yes & 5,9 & 69 & $4,5-7,3$ \\
\hline No & 94,1 & 1101 & $92,7-95,5$ \\
\hline \multicolumn{4}{|c|}{ Physical activity level } \\
\hline Insufficiently Active & 81,5 & 953 & $16,3-20,7$ \\
\hline Sufficiently Active) & 18,5 & 217 & $79,3-83,7$ \\
\hline
\end{tabular}

Note - Cl: Confidence Interval.

In relation to the gross analysis (table 2) to socio-demographic variables, the single students $\left(\mathrm{OR}_{\text {gross }}=1.514 ; 95 \% \mathrm{CI}: 1.005-2.280\right)$, who didn't work $\left(\mathrm{OR}_{\text {gross }}=1.913 ; 95 \% \mathrm{CI}\right.$ : 1.352-2.707) and with mothers with under eight years of education $\left(\mathrm{OR}_{\text {gross }}=1.635 ; 95 \% \mathrm{CI}: 1.187-2.253\right)$ showed higher chances of excessive time watching television. After the adjusted analysis (table 2), the unemployed $\left(\mathrm{OR}_{\text {adjusted }}=1.940\right.$; 95\%CI: $1.365-2.758)$, those whose mothers had less than eight years of education $\left(\mathrm{OR}_{\text {adjusted }}=1.324\right.$; 95\% CI: 1.023 1.714) and those with inadequate consumption of vegetables $\left(\mathrm{OR}_{\text {adjusted }}=1.423 ; 95 \% \mathrm{CI}\right.$ : 1.082-1.871) showed significantly higher odds of having excessive screen time watching television (Table 2). 
On analysing the excessive time using computer/ video games, in the gross analysis (table 3), female students (ORgross $=0.667$; 95CI: 0.51-0.864) and those with monthly household income lower than two minimum wages (ORgross $=0.605$; 95\%CI: 0.459-0.797) showed lower chances of excessive screen time. In relation to lifestyle, those who did not achieve the minimum weekly consumption of vegetables $\left(\mathrm{OR}_{\text {gross }}=1.374 ; 95 \% \mathrm{CI}\right.$ : 1.046-1.805) showed higher chances of exposure to the behaviour.
After the adjusted analysis (table 3), women $\left(\mathrm{OR}_{\text {adjusted }}=0.694 ; 95 \% \mathrm{I}: 0.528-0.912\right)$, as well as those with family income of less than two minimum wages $\left(\mathrm{OR}_{\text {adjusted }}=0.630 ; 95 \% \mathrm{CI}: 0.474-0.838\right)$ showed lower chances of exposure to the outcome, while the insufficiently active $\left(\mathrm{OR}_{\text {adjusted }}=1.557 ; 95 \% \mathrm{CI}\right.$ : 1.076 - 1.972) showed significantly higher chances of excessive screen time using computer/video games (Table 3).

Table 2. Logistic regression analysis with estimates of odds ratios for the screen time watching television. according to sociodemographic and lifestyle variables. Jequié. Bahia. Brazil. 2015

\begin{tabular}{|c|c|c|c|c|c|}
\hline Variables & $\%$ & OR Gross (IC95\%) & $\mathbf{p}$ & OR Adjusted (IC95\%) & p \\
\hline \multicolumn{6}{|c|}{ Socio demographical } \\
\hline \multicolumn{6}{|l|}{ Gender } \\
\hline Female & 61.4 & $1.231(0.959-1.581)$ & 0.103 & $1.105(0.853-1.431)$ & 0.450 \\
\hline Male & 38.6 & 1 & & 1 & \\
\hline \multicolumn{6}{|l|}{ Age (years) } \\
\hline$<14$ & 3.4 & $2.053(0.905-4.657)$ & 0.085 & $1.710(0.739-3.958)$ & 0.210 \\
\hline $15-16$ & 48.6 & $1.793(1.045-3.076)$ & 0.034 & $1.527(0.873-2.672)$ & 0.138 \\
\hline $17-18$ & 40.7 & $1.625(0.941-2.806)$ & 0.082 & $1.443(0.950-2.198)$ & 0.204 \\
\hline$>19$ & 7.3 & 1 & & 1 & \\
\hline \multicolumn{6}{|l|}{ School Grade } \\
\hline $1^{\circ}$ & 46.2 & $1.206(0.894-1.627)$ & 0.220 & - & - \\
\hline $2^{\circ}$ & 27.0 & $0.849(0.611-1.178)$ & 0.327 & & \\
\hline $3^{\circ}$ & 26.8 & 1 & & & \\
\hline \multicolumn{6}{|l|}{ Marital Status } \\
\hline Single & 91.1 & $1.514(1.005-2.280)$ & 0.047 & $1.433(0.944-2.176)$ & 0.091 \\
\hline Married & 8.9 & 1 & & 1 & \\
\hline \multicolumn{6}{|l|}{ Occupation } \\
\hline Does not work & 87.4 & $1.913(1.352-2.707)$ & 0.001 & $1.940(1.365-2.758)$ & 0.001 \\
\hline Works & 12.6 & 1 & & 1 & \\
\hline \multicolumn{6}{|l|}{ Mother schoolarity } \\
\hline \multicolumn{6}{|l|}{ (years of study) } \\
\hline$<8$ years & 42.0 & $1.291(1.005-1.58)$ & 0.046 & $1.324(1.023-1.714)$ & 0.033 \\
\hline$>8$ years & 58.0 & 1 & & 1 & \\
\hline \multicolumn{6}{|l|}{ Monthly Family } \\
\hline \multicolumn{6}{|l|}{ Income (Minimum) } \\
\hline$<02$ salaries & 73.5 & $1.191(0.905-1.567)$ & 0.211 & - & - \\
\hline$>02$ salaries & 26.5 & 1 & & & \\
\hline \multicolumn{6}{|l|}{ Lifestyle } \\
\hline \multicolumn{6}{|l|}{ Fruit consumption } \\
\hline Inadequate & 51.3 & $0.817(0.638-1.045)$ & 0.108 & $0.712(0.245-0.929)$ & 0.012 \\
\hline Adequate & 48.7 & 1 & & 1 & \\
\hline \multicolumn{6}{|c|}{ Vegetable consumption } \\
\hline Inadequate & 64.5 & $1.266(0.980-1.636)$ & 0.071 & $1.423(1.082-1.871)$ & 0.012 \\
\hline Adequate & 35.5 & 1 & & 1 & \\
\hline \multicolumn{6}{|c|}{ Alcohol consumption } \\
\hline Yes & 24.7 & $1.076(0.809-1.433)$ & 0.614 & - & - \\
\hline No & 75.3 & 1 & & & \\
\hline \multicolumn{6}{|c|}{ Tabaco consumption } \\
\hline Yes & 95.0 & $0.785(0.456-1.353)$ & 0.384 & - & - \\
\hline No & 5.0 & 1 & & & \\
\hline \multicolumn{6}{|c|}{ Physical activity level } \\
\hline \multirow[t]{2}{*}{ Insufficiently active } & 83.7 & $0.793(0.573-1.096)$ & 0.160 & $0.894(0.638-1.253)$ & 0.516 \\
\hline & 83.7 & & & & \\
\hline Sufficiently active & 16.3 & 1 & & & \\
\hline
\end{tabular}

Note - OR: OddsRatio; Cl: confidence interval Values in bold: $p<0.05$. 
Table 3: Regression analysis for the screen time for computer / video game, according to sociodemographic and lifestyle variables. Jequié, Bahia, Brazil, 2015

\begin{tabular}{|c|c|c|c|c|c|}
\hline Variables & $\%$ & OR Gross (IC95\%) & p & OR Adjusted (IC95\%) & p \\
\hline \multicolumn{6}{|c|}{$\begin{array}{l}\text { Socio demographical } \\
\text { Gender }\end{array}$} \\
\hline Female & 50,8 & $0,667(0,514-0,864)$ & 0,002 & $0,694(0,528-0,912)$ & 0,009 \\
\hline Male & 49,2 & 1 & & 1 & \\
\hline \multicolumn{6}{|l|}{ Age (years) } \\
\hline$<14$ & 3,4 & $1,588(0,657-3,840)$ & 0,304 & $1,353(0,552-3,320)$ & 0,509 \\
\hline $15-16$ & 48,6 & $1,738(0,978-3,087)$ & 0,059 & $1,548(0,859-2,791)$ & 0,146 \\
\hline $17-18$ & 40,7 & $1,484(0,829-2,657)$ & 0,184 & $1,368(0,755-2,477)$ & 0,302 \\
\hline$>19$ & 7,3 & 1 & & 1 & \\
\hline \multicolumn{6}{|l|}{ School grade } \\
\hline $1^{\circ}$ & 43,8 & $1,257(0,910-1,737)$ & 0,165 & $1,113(0,769-1,611)$ & 0,569 \\
\hline $2^{\circ}$ & 31,9 & $1,221(0,865-1,723)$ & 0,257 & $1,152(0,803-1,655)$ & 0,445 \\
\hline $3^{\circ}$ & 24,3 & 1 & & 1 & \\
\hline \multicolumn{6}{|l|}{ Marital Status } \\
\hline Single & 88,3 & $0,991(0,663-1,483)$ & 0,967 & - & - \\
\hline Married & 11,7 & 1 & & & \\
\hline \multicolumn{6}{|l|}{ Occupation } \\
\hline Does not work & 83,6 & $1,244(0,883-1,752)$ & 0,211 & - & - \\
\hline Works & 16,4 & 1 & & & \\
\hline \multicolumn{6}{|c|}{ Mother schoolarity (years of study) } \\
\hline$<8$ years & 33,4 & $0,766(0,584-1,005)$ & 0,054 & $0,865(0,653-1,146)$ & 0,312 \\
\hline$\geq 8$ years & 66,6 & 1 & & 1 & \\
\hline \multicolumn{6}{|c|}{ Monthly Family Income (minimum) } \\
\hline$<02$ salaries & 63,4 & $0,605(0,459-0,797)$ & 0,000 & $0,630(0,474-0,838)$ & 0,009 \\
\hline$\geq 02$ salaries & 36,3 & 1 & & 1 & \\
\hline \multicolumn{6}{|l|}{ Lifestyle } \\
\hline \multicolumn{6}{|l|}{ Fruit consumption } \\
\hline Inadequate & 58,1 & $1,204(0,926-1,565)$ & 0,166 & $1,092(0,828-1,442)$ & 0,532 \\
\hline Adequate & 41,9 & 1 & & 1 & \\
\hline \multicolumn{6}{|c|}{ Vegetable consumption } \\
\hline Inadequate & 66,2 & $1,374(1,046-1,805)$ & 0,022 & $1,299(0,983-1,716)$ & 0,065 \\
\hline Adequate & 33,8 & 1 & & 1 & \\
\hline \multicolumn{6}{|c|}{ Alcohol consumption } \\
\hline Yes & 25,0 & $1,099(0,813-1,484)$ & 0,540 & - & - \\
\hline No & 75,0 & 1 & & & \\
\hline \multicolumn{6}{|c|}{ Tabaco consumption } \\
\hline Yes & 6,3 & $1,145(0,667-1,964)$ & 0,624 & - & - \\
\hline No & 93,7 & 1 & & & \\
\hline \multicolumn{6}{|c|}{ Physical activity level } \\
\hline Insufficiently active & 84,9 & $1,389(0,978-1,972)$ & 0,066 & $1,557(1,076-1,972)$ & 0,019 \\
\hline Sufficiently active & 15,1 & 1 & & 1 & \\
\hline
\end{tabular}

Note - OR: oddsratio; Cl: confidence interval: Values in bold: $p<0,005$.

\section{DISCUSSION}

The prevalence of excessive time watching television was $32.8 \%$. Estimates of prevalence values of this behaviour are quite different according to national ${ }^{5,10}$ and international4 studies. In relation to the excessive time using computer/video games, the prevalence rate was $27.3 \%$. National $^{23-27}$ and international ${ }^{28,29}$ studies also showed differences in estimated values for this behaviour.

Female students presented lower chances of exposure to excessive screen time using computer/video games, not noted in their time watching television. A previous systematic review showed that, in relation to excessive screen time, there was a trend of association to female gender ${ }^{29}$. However, most of the studies found in the review assessed the total screen time. Another systematic review 9 noted that, in most studies, male teenagers were using more computer or video games as forms of entertainment in comparison to females, providing possible justification for the result of this study.
In relation to the family's monthly income, those individuals where the family received less than two minimum wages presented lower chances of exposure to excessive screen time using computer/video games. This result is explained by the fact that this subgroup possibly has low access to equipment, since the national survey on synthesis of social indicators, held in $2014^{30}$, on the basis of analysing lower income families, showed that, in the more developed States (South and Southeast), around $16.0 \%$ of households had a computer, internet access and other goods, whereas, in the Northeastern region, only $5.7 \%$ had access to the same services.

The students who did not work were more likely to spend too much time watching television. Data from the Brazilian Institute of Geography and Statistics (IBGE)30 indicated that, in Brazil, legally, from the age of 15, the only paid work that is legally permitted is as an apprentice, and that the level of employment of those between 16 and 17 years of age was $27.4 \%$ in 2014 . The scholars who did not work presented higher chances of exposure to exces- 
sive screen time watching television. Watching television is an attractive activity, with several programs targeted at schoolchildren in this age range ${ }^{28}$, adding to the fact that no work can involve greater free time. In the students that were not working, an association with the sedentary behaviour using computer/video games was not observed in the present study. As computers or video games are expensive, it is believed that students who do not work do not have financial independence and do not contribute in the family budget, as observed mainly in the family income ${ }^{31}$. Even families with low income mostly have television sets at home, which is not the case for computers or video games, especially in less developed regions ${ }^{30}$.

Those whose mothers had less than eight years of education showed higher chances of exposure to excessive time watching television. Other studies ${ }^{13,16}$ have shown that a low educational level of parents or guardians is correlated with excessive screen time watching television. Since most of the studies used the measurement of screen time that involved adding the behaviours, studies that verify the relation of educational level of mothers with the use of computer/video games alone were not found, as highlighted in systematic reviews ${ }^{9,13}$. It is believed that greater educational and economic levels of mothers positively influence healthier behaviours, in addition to allowing them to realise the health risks of children in relation to excessive exposure to television ${ }^{12,16}$.

Dietary habits were associated with excessive time in front of the television, since those who had an inadequate level of consumption of vegetables, presented higher chances of exposure to the behaviour. However, it was not observed in relation to the use of computer/video games. A systematic review ${ }^{32}$ revealed that $85 \%$ of the items investigated have shown an association between low consumption of fruits or vegetables, as well as high consumption of salted or soft drinks and excessive time watching television.

The authors indicated that, generally, when watching television or using computers students tend to ingest unhealthy food (soft drinks and snacks), decreasing the possibility of healthy foods consumption ${ }^{32}$.

Inadequate consumption of fruits showed lower chances of exposure to the behaviour. Regardless of this result, low consumption of fruits and vegetables is a public health problem in adolescents ${ }^{32}$ and, according to the report of the World Health Organization (WHO) in 2005, it was estimated that low intake of fruits and vegetables was the eighth most important cause of death in developed countries $^{33}$.

Thus, stimulating healthy eating from childhood onwards, through speeches by parents and schools, is critical to the prevention of diseases and non-communicable diseases, in particular overweightness and obesity $^{34,35}$.

Those deemed "insufficiently active" showed higher chances of exposure to excessive time using computer/ video games, which was not observed in relation to the time watching television. Previous research16 has found that the only variable associated, even in low magnitude, to excessive time watching television and using a computer, in the same sample was physical inactivity ${ }^{16}$.

Physical activity and sedentary behaviour are different constructs, with different factors. Exposure to screen time does not necessarily present adverse conditions for the practice of physical activities (lower perception of self-efficacy, less social support and appropriate environments) ${ }^{10}$. However, other studies 11,34 have reinforced the idea that the higher the level of physical activity the lower the prevalence of sedentary behaviour.

The differences and limitations found in the literature regarding the prevalence and related values are probably due to age range, the instruments used (diversity found in literature), the scales of the measures (energy expenditure or reminder) and the cut-off points (different criteria), as highlighted in the systematic review ${ }^{29}$.

The use of auto-administered questionnaire, even if it has been validated and tested, can create a bias of information for some variables, since participants do not always have clear information about these behaviours, which can influence the estimates of prevalence, presenting a limitation of the present study. However, the study is a pioneer in the region of Bahia, producing consistent data, as part of monitoring of risk behaviour in students.

It is concluded that about $1 / 3$ of the students of a city in the Brazilian Northeast watched television and used computer/video games excessively. Female students and those with family income below two minimum wages presented lower chances of exposure to excessive screen time using computer/video games, however, those insufficiently active showed higher chances.

Those individuals who were not working, whose mothers had less than eight years of study and with inadequate consumption of vegetables presented higher chances of exposure to excessive screen time watching television. Finally, those with inadequate consumption of fruits showed lower chances of exposure to excessive screen time watching television. These findings suggest that behaviours differ from one group to another, providing consistent data to the education and public health agencies.

\section{REFERENCES}

1. Owen N, Healy GN, Matthews CE, Dunstan DW. Too much sitting: the population health science of sedentary behavior. Exerc Sport Sci Rev. 2010;38(3):105-13. DOI: htpp://dx.doi.org/10.1097/JES.0b013e3181e373a2

2. Sedentary Behaviour Research Network. Letter to the editor: standardized use of the terms "sedentary" and "sedentary behaviours". Appl Physiol Nutr Metab. 2012;37: 540-2. DOI: htpp://dx.doi.org/10.1139/ H2012-024

3. American Academy of Pediatrics. Children, adolescents, and television. Pediatr. 2001;107(2):423-6.

4. Currie C, Gabhainn SN, Godeau E, Roberts C, Smith R, Currie D, et al. Inequalities in young people's health: HBSC international report from the 2005/2006 survey. World Health Organization; 2008. 
5. Instituto Brasileiro de Geografia e Estatística (IBGE). Pesquisa Nacional de Saúde do Escolar 2012. Rio de Janeiro: IBGE; 2013.

6. Brodersen $\mathrm{NH}$, Steptoe A, Boniface DR, Wardle J. Trends in physical activity and sedentary behaviour in adolescence: ethnic and socioeconomic differences. Br J Sports Med. 2007;41(3):140-4. DOI: htpp:// dx.doi.org/10.1136/bjsm.2006.031138

7. Boone JE, Gordon-Larsen P, Adair LS, Popkin BM. Screen time and physical activity during adolescence: longitudinal effects on obesity in young adulthood. Int Jl of Beh Nutri and Phys Act. 2007;4:26. DOI: htpp:// dx.doi.org/10.1186/1479-5868-4-26

8. Pate RR, Mitchell JA, Byun W, Dowda M. Sedentary behaviour in youth. Br J Sports Med. 2011;45(11):90613. DOI: htpp://dx.doi.org/10.1136/bjsports-2011-090192

9. Van Der Horst K, Paw MJ, Twisk JW, Van Mechelen W. A brief review on correlates of physical activity and sedentariness in youth. Med Sci Sports Exerc. 2007; 39(8):1241-50. DOI: htpp://dx.doi.org/10.1249/ mss.0b013e318059bf35

10. Lucena JMS, Cheng LA, Cavalcante TLM, Silva VA, Farias Júnior JC. Prevalence of excessive screen time and associated factors in adolescents. Rev Paul Pediatr. 2015; 33(4):407-14. DOI: http://dx.doi. org/10.1016/j.rpped.2015.04.001

11. TammelinT, Ekelund U, Remes J, Näyhä S. Physical activity and sedentary behaviors among Finish youth. Med Sci Sports Exerc. 2007; 39 (7):1067-74. DOI: http://dx.doi.org/10.1249/mss.0b13e318058a603

12. MacLeod KE, Gee GC, Crawford P, Wang MC. Neighbourhood environment as a predictor of television watching among girls. J Epidemiol Community Health. 2008; 62(4):288-92. DOI: http://dx.doi.org/10.1136/ jech.2007.061424

13. Zabinski MF, Norman GJ, Sallis JF, Calfas KJ, Patrick K. Patterns of sedentary behavior among adolescents. Health Psychol. 2007;26(1):113-20. DOI: http://dx.doi.org/10.1037/0278-6133.26.1.113

14. Sisson SB, Church TS, Martin CK, Tudor-Locke C, Smith SR, et al. Profiles of sedentary behavior in children and adolescents: The US national health and nutrition examination survey, 2001-2006. Int J Pediatr Obes. 2009;4(4):353-9. DOI: http://dx.doi.org/10.3109/17477160902934777

15. Sisson SB, Broyles ST, Baker BL, Katzmarzyk PT. Television, reading, and computer time: Correlates of school-day leisure-time sedentary behavior and relationship with overweight in children in the U.S. J Phys Act Health. 2011;8(suppl. 2): S188-97. DOI: http://dx.doi.org/10.1123/jpah.8.s2.s188

16. Babey SH, Hastert TA, Wolstein J. Adolescent sedentary behaviors: correlates differ for television viewing and computer use. J Adol Health. 2013;52(1):70-6. DOI: http://dx.doi.org/10.1016/j.jadohealth.2012.05.001

17. Instituto Brasileiro de Geografia e Estatística (IBGE). Cidades. [cited 2016 Fev 20] Available from: http:// cidades.ibge.gov.br/xtras/perfil.php?lang=\&codmun=291800\&search=bahialjequie.

18. Luiz RR, Magnanini MMF. A lógica da determinação do tamanho da amostra em investigações epidemiológicas. Cad Saúde Colet. 2000;8(2):9-28.

19. Silva KS, Lopes AS, Hoelfelmann LP, Cabral LGA, De Bem MFA, Barros MVG, et al. Health risk behaviors project (COMPAC) in youth of the Santa Catarina State, Brazil: ethics and methodological aspects. Braz J Kin Hum Per. 2013;15(1):1-15. DOI: http://dx.doi.org/10.5007/1980-0037.2013v15n1p1

20. World Health Organization (WHO). Global recommendations on physical activity for health. Geneva: World Health Organization; 2010.

21. Reichenheim ME, Coutinho ES. Measures and models for causal inference in cross-sectional studies: arguments for the appropriateness of the prevalence odds ratio and related logistic regression. BMC Med Res Methodol. 2010;10:66. DOI: http://dx.doi.org/10.1186/1471-2288-10-66

22. Szwarcwald CL, Damacena GN. Amostras complexas em inquéritos populacionais: planejamento e implicações na análise estatística dos dados. Rev Bras Epidemiol. 2008;11(suppl 1):38-45. DOI: http://dx.doi. org/10.1590/S1415-790X2008000500004

23. Silva DAS, Tremblay MS, Gonçalves ECA, Silva RJS. Television time among Brazilian adolescents: correlated factors are different between boys and girls. Sci World J. 2014;2014:9. DOI: http://dx.doi. org/10.1155/2014/794539

24. Silva KS, Nahas MV, Hoefelmann LP, Lopes AS, Oliveira ES. Associations between physical activity, body mass index, and sedentary behaviors in adolescents. Rev Bras Epidemiol. 2008;11(1):159-68. DOI: http:// dx.doi.org/10.1590/S1415-790X2008000100015

25. Kann L, Kinchen S, Shanklin SL, Flint KH, Kawkins J, Harris WA, et al. Youth risk behavior surveillance United States, 2013. MMWR Surveill Summ. 2014;63(suppl4):1-168.

26. Stierlin AS, Lepeleere S, Cardon G, Dargent-Molina P, Hoffman B, Murphy MH, et al. A systematic review of determinants of sedentary behaviour in youth: a DEDIPAC study. Int J Behav Nutr Phys Act. 2015;12:133. DOI: http://dx.doi.org/10.1186/s12966-015-0291-4

27. Hardman CM, Barros MVG, Lopes AS, Lima RA, Bezerra J, Nahas MV. Effectiveness of a school-based intervention regarding screen time in high school students. Rev Bras Cineantropom Desempenho Hum. 2014;16(Supl. 1): 25-35. DOI: http://dx.doi.org/10.5007/1980-0037.2014v16s1p25

28. Telford RM, Telford RD, Cunningham RB, Cochrane T, Davey R, Waddington G. Longitudinal patterns of physical activity in children aged 8 to 12 years: the LOOK study. Int J Behav Nutr Phys Act. 2013;10:81. DOI: http://dx.doi.org/10.1186/1479-5868-10-81 
29. Barbosa Filho VC, Campos W, Lopes AS. Epidemiology of physical inactivity, sedentary behaviors, and unhealthy eating habitsamong Brazilian adolescents: a systematic review. Cienc Saude Coletiva. 2014;19(1):173-93. DOI: http://dx.doi.org/10.1590/1413-81232014191.0446

30. Instituto Brasileiro de Geografia e Estatística (IBGE). Síntese de indicadores sociais - uma análise das condições de vida da população brasileira. Rio de Janeiro: 2014.

31. Oliveira DC, Fischer FM, Teixeira MCTV, Sá CP, Gomes AMT. Representações sociais do trabalho: uma análise comparativa entre jovens trabalhadores e não trabalhadores. Ciên Saúde Coletiva. 2010;15(3):76373. DOI: http://dx.doi.org/10.1590/S1413-81232010000300019

32. Rossi CE, Albernaz DO, Vasconcelos FAG, Assis MAA, Di Pietro PF. Influência da televisão no consumo alimentar e na obesidade em crianças e adolescentes: uma revisão sistemática. Rev Nutr. 2010;23(4):60720. DOI: http://dx.doi.org/10.1590/S1415-52732010000400011

33. World Health Organization (WHO). Preventing Chronic Diseases a vital investment. Geneva: World Health Organization; 2005.

34. Ceschini FL, Andrade DR, Oliveira LC, Araújo Júnior JF, Matsudo VKR. Prevalência de inatividade física e fatores associados em estudantes do ensino médio de escolas públicas estaduais. J Pediatr (Rio J). 2009;85(4):301-6. DOI: http://dx.doi.org/10.1590/S0021-75572009000400006

35. Bello FPS, Chagas NB, Pinto VLM, Camargo LLAL, Demarzo MMP, Germano CMR. Parental awareness of overweight and obesity: and exploratory study address in glow-income adolescents. J Hum Growth Dev. 2015;25(3):292-6. DOI: http://dx.doi.org/10.7322/jhgd.106000

This article is distributed under the terms of the Creative Commons Attribution 4.0 International License (http://creativecommons.org/licenses/by/4.0/), which permits unrestricted use, distribution, and reproduction in any medium, provided you give appropriate credit to the original author(s) and the source, provide a link to the Creative Commons license, and indicate if changes were made. The Creative Commons Public Domain Dedication waiver (http://creativecommons.org/publicdomain/zero/1.0/) applies to the data made available in this article, unless otherwise stated.

\section{Resumo:}

Introdução: Estudos sobre o tempo de tela e seus correlatos geralmente são determinados pelo somatório dos tempos de vários comportamentos. Pesquisas que analisaram comportamentos separadamente evidenciaram diferentes correlatos.

Objetivo: Estimar prevalência de tempo excessivo de tela ( $\geq 2$ horas/dia), durante os dias da semana, em televisão e uso de computador/videogame e verificar a associação aos fatores sociodemográficos e do estilo de vida em escolares.

Método: Levantamento com amostra de escolares do ensino médio $(n=1.163)$, de 14 a 20 anos de idade, residentes em Jequié/BA, Brasil. As variáveis dependentes foram tempo excessivo assistindo televisão e usando computador/videogame, e as independentes foram, as sociodemográficas e do estilo de vida. A magnitude das associações foi determinada pela Odds Ratio(OR) e intervalos de confiança (IC) de 95\% (IC95\%).

Resultados: A prevalência de tempo excessivo assistindo televisão foi estimada em 32,8\% (IC95\%: $29,9 \%$ - 35,5\%) e usando computador/videogame 27,3\% (IC95\%: $24,5 \%$ - 29,5\%). Os que não trabalhavam (OR =1,940; IC95\%: 1,365-2,758), aqueles cujas mães tinham menos de oito anos de estudo $(\mathrm{OR}=1,324 ; \mathrm{IC} 95 \%$ : 1,023 - 1,714) e que não consumiam verduras regularmente $(\mathrm{OR}=1,423$; IC95\%: 1,082 - 1,871) apresentaram maiores chances de exposição ao tempo excessivo televisão. Por outro lado, os que não atingiram o consumo mínimo de frutas (OR = 0,712; IC95\%: 0,245 - 0,929) apresentaram menores chances. Escolares do sexo feminino (OR = 0,694; IC95\%: 0,528 - 0,912) e aqueles com renda familiar inferior a dois salários mínimos (OR = 0,630; IC95\%: 0,474 - 0,838), apresentaram menores chances de exposição ao tempo excessivo utilizando computador/videogame e os insuficientemente ativos (OR = 1,557; IC95\%: 1,076 - 1,972), apresentaram maiores chances.

Conclusões: Cerca de $1 / 3$ dos escolares passavam tempo excessivo à frente da televisão e do computador/videogame, tendo correlatos distintos para cada comportamento.

Palavras-chave: sedentarismo, adolescentes, fatores de risco, comportamento. 